\title{
Genetics, development and evolution of adaptive pigmentation in vertebrates
}

\author{
HE Hoekstra \\ Division of Biological Sciences, University of California, San Diego, La Jolla, CA 92093-0116, USA
}

The study of pigmentation has played an important role in the intersection of evolution, genetics, and developmental biology. Pigmentation's utility as a visible phenotypic marker has resulted in over 100 years of intense study of coat color mutations in laboratory mice, thereby creating an impressive list of candidate genes and an understanding of the developmental mechanisms responsible for the phenotypic effects. Variation in color and pigment patterning has also served as the focus of many classic studies of naturally occurring phenotypic variation in a wide variety of vertebrates, providing some of the most compelling cases for parallel and convergent evolution. Thus, the pigmentation model system holds much promise for understanding the nature of adaptation by linking genetic changes to variation in fitness-related traits. Here, I first discuss the historical role of pigmentation in genetics, development and evolutionary biology. I then discuss recent empirically based studies in vertebrates, which rely on these historical foundations to make connections between genotype and phenotype for ecologically important pigmentation traits. These studies provide insight into the evolutionary process by uncovering the genetic basis of adaptive traits and addressing such longstanding questions in evolutionary biology as (1) are adaptive changes predominantly caused by mutations in regulatory regions or coding regions? (2) is adaptation driven by the fixation of dominant mutations? and (3) to what extent are parallel phenotypic changes caused by similar genetic changes? It is clear that coloration has much to teach us about the molecular basis of organismal diversity, adaptation and the evolutionary process.

Heredity (2006) 97, 222-234. doi:10.1038/sj.hdy.6800861; published online 5 July 2006

Keywords: adaptation; Agouti; candidate gene; color; gene regulation; Mc1r, Peromyscus

\section{Introduction}

Understanding the generation and maintenance of phenotypic diversity requires the integration of genetics, development and evolutionary biology in an ecological context. Historically, biologists have used two parallel approaches to study evolutionary change, one working at the level of genotype and a second working at the level of phenotype (Lewontin, 1974). For example, population geneticists have focused on temporal and spatial changes in allele and genotype frequencies, whereas organismal biologists have studied how individuals differ in phenotypic traits across natural environments. However, research linking genotype and phenotype (ie, identifying the molecular changes responsible for phenotypic adaptation and the developmental mechanisms by which genotypes encode phenotypic traits (eg, Carroll et al, 2001; Brakefield et al, 2003)) is necessary to truly understand the processes responsible for generating both genetic and organismal diversity.

The pigmentation system is a particularly promising phenotype in which to explore connections between genotype and phenotype for ecologically important traits. Coat color mutations in laboratory mice have served as a premier model for studying gene action in a

Correspondence: HE Hoekstra, Division of Biological Sciences, 9500 Gilman Drive, MC-0116, University of California, San Diego, La Jolla, CA 92093-0116, USA. E-mail: hoekstra@ucsd.edu

Received 30 January 2006; accepted 1 June 2006; published online 5 July 2006 variety of biological processes (Silvers, 1979), leading to a wealth of information about genes involved in pigmentation and their developmental interactions. Because melanin-based pigmentation biology is highly conserved across vertebrates, a deep understanding of mouse coat color genetics translates easily and directly into testable hypotheses for studying the molecular basis of pigmentation variation in natural vertebrate populations (Bennett and Lamoreux, 2003). Most important, color quality and/ or color patterns frequently exhibit dramatic variation both within and between species in a way that can be quantified (Endler, 1990) and is conspicuously affected by natural selection (Caro, 2005). In particular, selective forces such as crypsis, aposematism, thermoregulation, and sexual signaling drive variation in both pigmentation and color pattern (Thayer, 1909; Cott, 1940). Thus, pigmentation phenotypes in natural populations present an ideal opportunity for studying the genetic basis of phenotypic diversity and evolutionary change.

Here, I first discuss how the rich history of pigmentation biology in the fields of genetics, development and evolution provide the essential background information to address fundamental questions in evolutionary developmental biology. Then I provide empirical examples in which the link between genotype and phenotype has been successfully made for adaptive pigmentation in natural populations. Throughout, I focus primarily on studies of mice and melanin-based pigmentation, from which the most data are available, but draw on studies of other vertebrates and pigment types whenever possible. Together, these studies provide exciting insight into how 
adaptation proceeds at the molecular level and also shed light on the evolutionary process in general.

\section{History of pigmentation biology}

The study of pigmentation has played a critical role in the fields of genetics, development and evolution. Beginning in 18th century China and Japan, so-called mouse fanciers collected, maintained and bred together unusual morphs of wild mice (Morse, 1978); in doing so, these novice geneticists generated mice with a large diversity of color variation, much of which is represented today in laboratory mice. With the development of diverse mouse strains, pigmentation phenotypes were readily available for study, and much of our knowledge of the pigmentation process has subsequently come from studies of these laboratory mice. Correspondingly, observations of coat color variation, first in the laboratory and later in the field, have played an essential role in the understanding of many fundamental biological processes (Table 1).

\section{Genetics: the pigmentation loci}

In the early 1900s as Mendel's principles were rediscovered, coat color differences were used to test several fundamental theories of genetics, and 50 years later, mutations of the same genes provided the first estimates of mammalian mutation rates. As early as 1903 (before the term 'genetics' was even coined), independent experiments by Lucien Cuénot (1904) and William Castle and Allen (1903) first demonstrated Mendelian inheritance in mammals by documenting segregation patterns of albino phenotypes in genetic crosses. Then, in 1915, Haldane et al (1915) published the first genetic linkage study in vertebrates, establishing linkage between the pink-eyed dilution locus and the albino locus in the mouse. Parallel studies of pigmentation genetics in other vertebrate taxa provided additional early examples of genetic linkage, perhaps most notably in guppies (Winge, 1927).

Around the same time, Sewall Wright, under the tutelage of Castle, developed key experiments to demonstrate epistasis and pleiotropy using coat color variation in hooded rats - animals that were mostly white except for a pigmented area on the head and neck. In these experiments, the size of the pigmented area or 'hood' was selected to be small in some lines and large in others. Castle initially thought these size differences reflected different alleles of the major gene responsible for hooding; however, Wright showed that so-called modifier genes were responsible for variation in hood size, providing the first experimental demonstration of epistasis (Little, 1917). Wright's work with pigmentation in guinea pigs also revealed the importance of interactions within and among gene systems. Wright demonstrated that apparently unrelated or pleiotropic phenotypes can have a single underlying developmental mechanism, suggesting how adaptive change in one trait might easily dictate nonadaptive change in other traits. These classic experiments using coat color phenotypes clearly influenced the fields of quantitative and population genetics.

In the 1950s and 1960s, mouse coat color genetics became increasingly used as a test system for studying induced and spontaneous mutation. Arguably, the earliest and most comprehensive estimates of mammalian mutation rates relied directly on visible phenotypes, including a number of coat color loci (eg, agouti (a), brown $(b)$, albino $(c)$, dilute $(d)$, leaden $(\ln )$, pink-eyed dilution $(p)$ and piebald-spotting (s)). First, a student of Wright, William Russell created a T-stock mouse packed with seven recessive, viable, radiation-induced mutations, six of which were coat color mutations (Russell, 1951). By examining large numbers of progeny $(>85000)$ from crosses of T-stock mice to mutagenized animals, Russell was able to estimate the rate of heritable gene mutations, an approach later termed 'the specific locus test'. These experiments revealed a 10 times higher mutation rate in mammals relative to earlier estimates in Drosophila as well as a high degree of variation in mutability among loci (reviewed in Davis and Justice, 1998). This work was followed by a series of studies of spontaneous mutation rates in the 1960s, when large production colonies were carefully examined for spontaneous coat color variants; more than 100 new genes were identified (Schlager and

Table 1 Timeline of some milestones and fundamental discoveries using pigmentation phenotypes

\begin{tabular}{lll}
\hline Date & Milestone & Representative reference \\
\hline $1700 \mathrm{~s}$ & $\begin{array}{l}\text { Establishment of laboratory mouse strains with 'fancy' coat } \\
\text { color patterns } \\
\text { Demonstration of Mendelian inheritance in vertebrates using } \\
\text { the albino locus }\end{array}$ & Morse (1978) \\
$1902-1904$ & $\begin{array}{l}\text { Establishment of genetic linkage in mammals using two } \\
\text { pigmentation loci }\end{array}$ & Haldane et al (1915) \\
1915 & $\begin{array}{l}\text { Seminal papers on coat color genetics in laboratory animals } \\
\text { Natural history studies linking vertebrate pigmentation to } \\
\text { environmental variation }\end{array}$ & $\begin{array}{l}\text { Wright (1917a, b, c, d) } \\
\text { Sumner (1921, 1929a, b), Benson (1933), Dice and }\end{array}$ \\
1917 Blossom (1937) \\
1948 & $\begin{array}{l}\text { First mathematical treatment of clinal variation based on } \\
\text { adaptive pigmentation traits }\end{array}$ & Haldane (1948) \\
$1950 \mathrm{~s}$ & $\begin{array}{l}\text { First estimate of radiation-induced mammalian mutation rates } \\
\text { at six coat color loci }\end{array}$ & Russell (1951), Russell and Major (1957) \\
$1960 \mathrm{~s}$ & $\begin{array}{l}\text { Estimates of spontaneous mammalian mutation rates using } \\
\text { coat color phenotypes }\end{array}$ & Schlager and Dickie (1966, 1969) \\
1986 & $\begin{array}{l}\text { Cloning of the first pigmentation gene } \\
\text { Linking mutations in pigmentation genes to adaptive } \\
\text { phenotypic variation in the wild }\end{array}$ & Shibahara et al (1986) \\
& & \\
\hline
\end{tabular}


Dickie, 1966, 1967). Together, these studies highlight how pigmentation loci have provided a foundation for many fundamental concepts in genetics.

As a result of the tremendous utility of pigmentation phenotypes, a sizeable list of genetic loci with well- characterized phenotypes in mice has been accumulated (Table 2). The first pigmentation gene to be cloned, tyrosinase-related-protein-1 (Tyrp1), was initially thought to be the gene responsible for the albino mouse mutant, but albinism was later mapped, cloned, sequenced and

Table 2 Pigmentation genes that have been cloned and sequenced in laboratory mouse

\begin{tabular}{|c|c|c|c|}
\hline Gene & Classic mutant & Chrom $^{\mathrm{a}}$ & Function $^{\mathrm{b}}$ \\
\hline A disintergrin and metalloproteinase domain 17 (Adam17) & & 12 & a \\
\hline Adamts20 & Belted (bt) & 15 & a \\
\hline Ectodysplasin-A (Eda) & Tabby (ta) & $\mathrm{X}$ & a \\
\hline Endothelin 3 ligand (Edn3) & Lethal spotting (ls) & 2 & a \\
\hline Endothelin receptor B (Ednrb) & Piebald spotting (s) & 14 & a \\
\hline Epidermal growth factor receptor (Egfr) & Darkskin5 (dsk5) & 11 & a \\
\hline Fibroblast growth factor receptor 2 (Fgfr2) & & 7 & a \\
\hline Inhibitor of kappaB kinase gamma (Ikbkg) & & $\mathrm{X}$ & a \\
\hline C-kit receptor (Kit) & Dominant white-spotting $(\mathrm{W})$ & 5 & a \\
\hline Ligand for c-kit receptor (Kitl) & Steel (Sl) & 10 & a \\
\hline Keratin complex 2, gene 17 (Krt2-17) & Dark skin 2 (dsk2) & 15 & a \\
\hline LIM homeodomain protein 1 (Lmxla) & Dreher $(\mathrm{dr})$ & 1 & a \\
\hline Mucolipin 3 (Mcoln 3 ) & Variant-waddler (Va) & 3 & a \\
\hline Microphthalmia transcription factor (Mitf) & Microphthalmia (mi) & 6 & a \\
\hline Pax-3 transcription factor ( $\mathrm{Pa} 3)$ & Splotch $(\mathrm{Sp})$ & 1 & a \\
\hline Sideroflexin (Sfxn1) & Flexed tail & 13 & a \\
\hline Neural crest transcription factor (Snai2) & White spotting & 16 & a \\
\hline Sry-box-containing gene 10 (Sox10) & Dominant megacolon (Dom) & 15 & a \\
\hline Sry-box-containing gene 18 (Sox18) & Ragged (ra) & 2 & a \\
\hline Transcription factor AP-2 alpha (Tcfap2A) & & 13 & a \\
\hline T-box gene $($ tbx 15$)$ & Droopy ear (de) & 3 & a \\
\hline Tyrosinase-related protein 2 (Tyrp2/Dct) & Slaty (slt) & 14 & $\mathrm{~b}$ \\
\hline Glycoprotein (Gpnmb) & Iris pigment dispersion (ipd) & 6 & $\mathrm{~b}$ \\
\hline Membrane-associated transporter protein (Matp) & Underwhite (uw) & 15 & $\mathrm{~b}$ \\
\hline Member of RAS oncogene family (Rab38) & Chocolate (cht) & 7 & $\mathrm{~b}$ \\
\hline Silver protein (Pmel17) & Silver (si) & 10 & $\mathrm{~b}$ \\
\hline Solute carrier family 24 member 5 (Slc24a5) & Golden (gol) & 2 & $\mathrm{~b}$ \\
\hline Tyrosinase (Tyr) & Albino (c) & $\overline{7}$ & $\mathrm{~b}$ \\
\hline Tyrosinase-related protein 1 (Tyrp1) & Brown (b) & 4 & $\mathrm{~b}$ \\
\hline Beta 3 subunit of adaptor protein 3 (Ap3b1) & Pearl (pe) & 13 & c \\
\hline Bloc1s3 & Reduced pigmentation (rp) & 7 & c \\
\hline Delta subunit of adaptor protein 2 (Ap3d) & Mocha (mh) & 10 & c \\
\hline Dtnbp1 & Sandy (sdy) & 13 & $\mathrm{c}$ \\
\hline Cno & Cappuccino (cno) & 5 & c \\
\hline Hermansky-Pudlak syndrome gene 1 (Hps1) & Pale ear (ep) & 19 & c \\
\hline Hermansky-Pudlak syndrome gene 3 (Hps3) & Cocoa (coa) & 3 & c \\
\hline Hermansky-Pudlak syndrome gene 4 (Hps4) & Light ear (le) & 5 & c \\
\hline Hermansky-Pudlak syndrome gene 5 (Hps5) & Ruby-eye 2 (ru2) & 7 & $\mathrm{c}$ \\
\hline Hermansky-Pudlak syndrome gene 6 (Hps6) & Ruby eye (ru) & 19 & c \\
\hline Lysosomal trafficking regulator (Lyst) & Beige $(\mathrm{bg})$ & 13 & c \\
\hline Muted $(\mathrm{Mu})$ & Muted (mu) & 13 & $\mathrm{c}$ \\
\hline Ocular albinism type 1 (Oca1) & Oca1 (oca1) & $\mathrm{X}$ & c \\
\hline Ocular albinism type 2 (Oca2) & Pink-eyed dilution $(p)$ & 7 & $\mathrm{c}$ \\
\hline Pallidin (Pldn) & Pallid (pa) & 2 & c \\
\hline Rab geranylgeranyl transferase (Rabgtta) & Gunmetal (gm) & 14 & c \\
\hline Vacuolar protein sorting 33a (Vps33a) & Buff (bf) & 5 & $\mathrm{c}$ \\
\hline Melanophilin (Mlph) & Leaden $(\ln )$ & 1 & $\mathrm{~d}$ \\
\hline Myosin type Va (Myo5a) & Dilute (d) & 9 & $\mathrm{~d}$ \\
\hline Myosin type 7a (Myo7a) & Shaker-1 (sh-1) & 7 & $\mathrm{~d}$ \\
\hline RAS-associated protein (Rab27a) & Ashen (ash) & 9 & $\mathrm{~d}$ \\
\hline Agouti signaling protein (Asip) & Nonagouti (a) & 2 & $\mathrm{e}$ \\
\hline Attractin (Atrn) & Mahogany (mg) & 2 & e \\
\hline Gamma gluyltranspeptidase 1 (Ggt1) & Ggt1 & 10 & e \\
\hline Gl & Grey lethal (gl) & 10 & e \\
\hline Melanocortin-1 receptor (Mc1r) & Extension (e) & 8 & e \\
\hline E3 ubiquitin ligase (Mgrn1) & Mahoganoid (md) & 16 & e \\
\hline Proopiomelanocortin (Pomc1) & & 12 & e \\
\hline Solute carrier family 7 member 11 (Slc7a11) & Subtle grey (sut) & 3 & e \\
\hline ATPase (Atp7a) & Mottled (mo) & $\mathrm{x}$ & $\mathrm{f}$ \\
\hline
\end{tabular}

${ }^{\mathrm{a}} \mathrm{Mus}$ musculus chromosome position.

${ }^{b}$ Functional classes: a, melanocyte development; b, components of melanosomes; c, melanosome construction; $d$, melanosome transport; e, melanin synthesis and switching; $f$, systemic effects. Modified from Oetting WS, Bennett DC. Mouse Coat Color Genes. International Federation of Pigment Cell Societies. URL: http://www.cbc.umn.edu/ifpcs/micemut.htm (references therein). 
correctly attributed to the tyrosinase locus (Jackson, 1988; Kwon et al, 1989). Since then, nearly 100 genes affecting pigmentation have been cloned in mice, but almost an equal number have yet to be identified (Bennett and Lamoreux, 2003), and new loci are accumulating as a result of chemical mutagenesis programs (Mouse Genome Database). In addition, complementary vertebrate systems, such as zebrafish, are providing additional pigmentation genes (Haffter et al, 1996; Odenthal et al, 1996; Kelsh et al, 2004), one of which (Slc24a5) has recently been linked to variation in human skin coloration (Lamason et al, 2006). Together, these loci provide excellent candidates for studying adaptive variation in natural populations of vertebrates.

\section{Development: the pigmentation pathway}

The characterization of pigmentation loci has provided considerable insight into fundamental developmental processes and a detailed understanding of the pigmentation pathway. In vertebrates, melanin-based pigmentation is the culmination of a complex process including the inception, migration and regulation of melanocytes (reviewed in Jackson, 1994). Based on studies in mammals, changes in melanocyte development and regulation ultimately lead to two primary ways in which variation in pigmentation phenotype is generated: (1) altering the spatial distribution of pigmentation across the body or (2) altering the density or distribution of pigmentation along individual hairs. Both of these strategies can have profound effects on overall appearance, but likely have a distinct genetic basis and are manifested in different parts of the developmental pathway. While there has been a growing interest in understanding how pigmentation patterns are generated, the most careful dissection of the pigmentation pathway has focused on regulation of melanocytes.

\section{Pigmentation patterning}

Pigmentation patterning has long captured the interest of biologists, largely because of the tremendous diversity in color pattern among animals, from butterfly wing spots to zebra stripes. In vertebrates, several mechanisms may contribute to regional variation in melanin type and density. During vertebrate embryogenesis, neural crest cells arise along the dorsal neural tube, and some differentiate into melanoblasts (precursors of melanocytes), which migrate ventrally along the body. Melanoblasts typically enter the epidermis, where some remain, while others localize to the hair follicles and differentiate into melanocytes. These melanocytes produce pigment (melanocyte regulation is discussed in detail below), and, once pigment is produced, it is packaged into melanosomes and transferred to keratinocytes of developing hair (or epidermal cells). Therefore, genes involved in patterning likely act early in development and are involved in melanocyte differentiation, development and migration.

While several genes essential for proper melanocyte development and dispersal have been identified (Table 2, Baxter et al, 2004), little is known about their spatial and temporal control. It has been postulated that developmental timing plays an important role in generating regular patterns; for example, subtle differences in the timing of melanocyte differentiation could be responsible for variation in the number of stripes among zebra species (Bard, 1977). However, the genes regulating these differences in timing remain unknown. The question of which genes are responsible for generating regional differences in pigmentation is a difficult one, largely because patterning variation in genetically tractable laboratory mouse strains is lacking and therefore not available for study. In mice, most progress in understanding patterning has been made in uncovering genes which determine differences in dorsal-ventral pigmentation.

Most vertebrates have a distinct boundary between dorsal and ventral pigmentation, typically characterized by a light colored ventrum and a darker dorsum (Figure 1). In mice, allelic variation at the agouti locus is largely responsible for dorsoventral differences in pigment type (Bultman et al, 1992; Miller et al, 1993; Millar et al, 1995). Careful dissection of the agouti regulatory region has revealed two major transcript initiation sites, one for a ventral-specific transcript, which is likely responsive to positional cues established in the embryo, and a second 'hair cycle-specific' transcript involved in switching between alternative types of melanins (described below, Bultman et al, 1994; Vrieling et al, 1994). The developmental mechanisms responsible for melanocyte density and differentiation along the dorsoventral axis likely involve the interactions of many proteins. How additional proteins may interact with or spatially regulate Agouti represents a first step in understanding how more complex patterns are generated.

The recent cloning of the gene responsible for the classical droopy ear (de) mouse mutant provides a first glimpse into developmental mechanisms that may be responsible for ecologically relevant variation in the spatial distribution of pigment across the body (Figure 1). The droopy ear phenotype produces a lateral shift in the dorsal-ventral boundary by allowing expansion of the
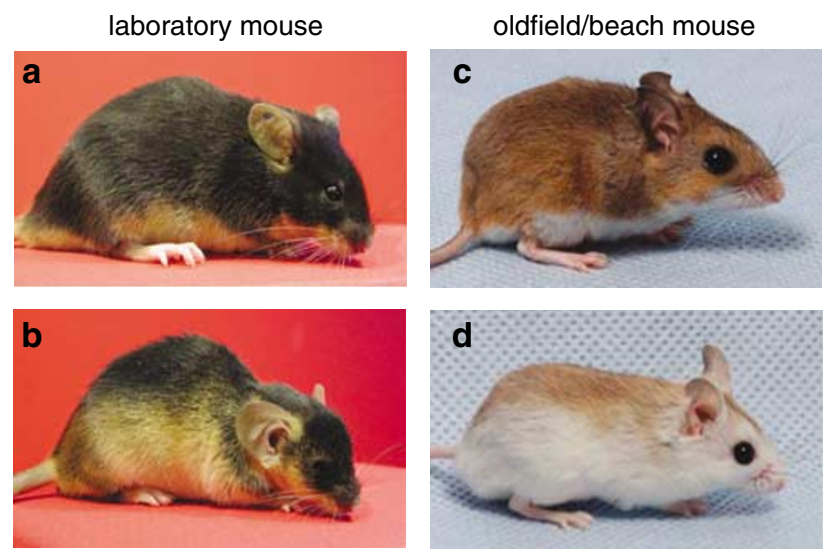

Figure 1 Variation in dorsoventral pattern in laboratory mice and natural populations of $P$. polionotus. A large deletion in the transcription-box 15 (Tbx15) gene results in a lateral shift in the dorsal-ventral boundary (and modifications of craniofacial morphology) as shown in this laboratory mouse (a and $\mathbf{b}$; on the Agouti black and tan genetic background) described by Candille et al (2004). A similar color pattern phenotype is observed in natural populations of beach mice relative to their darker mainland conspecific, the oldfield mouse (c and d). Spontaneous laboratory mutants can mimic naturally occurring phenotypic variation and provide candidate genes for adaptive traits. 
ventral-specific Agouti transcript (Figure 1b, Candille et al, 2004). This shift in pigmentation is caused by a null allele of the spatially restricted T-box transcription factor (Tbx15), which likely acts as a developmental cue required to establish dorsal dermis (Candille et al, 2004). Importantly, several developmental genes, like Tbx15, may not directly participate in the pigmentation pathway, but rather indirectly affect pigmentation as a secondary consequence of its role in cellular differentiation. In either case, this result is particularly exciting because similar patterning phenotypes occur in nature (Figure 1c and d), highlighting the possible utility of candidate genes in studies of natural populations.

Additional research is needed to understand the genetic basis and developmental origins of color patterning. In particular, proteins with patterned expression in the dermis such as Agouti, Tbx15 or others like Msx1 (Houzelstein et al, 2000) that may form distinct boundaries/gradients in developing embryos are particularly relevant. Such proteins are strong candidates for spatial patterning of hair pigmentation in different body regions and may even be involved in the formation of more complex lateral stripes observed in many vertebrates, like some snakes, lizards and ground squirrels. Additional insights will likely come from the zebrafish model system, which shows ample variation in both striping and spotting (Parichy, 2003; Kelsh, 2004), and from emerging model systems, like Peromyscus, where the combination of natural variation in patterning, ability to breed in the lab and new genomic tools make it possible to identify genes, and even the molecular changes, contributing to adaptive mammalian patterning (Hoekstra et al, in press).

\section{Whole-body changes in pigmentation}

One aspect of mammalian pigmentation that has been a frequent substrate for natural variation is the regulation and distribution of pigment types produced by melanocytes. In mammals, there are two types of pigments: eumelanin, which is responsible for black to brown color, and pheomelanin, which is responsible for red to yellow color. In melanocytes, several genes are involved in the coordination of 'pigment type-switching' between the synthesis of eumelanin and pheomelanin (Barsh, 1996). This switch is controlled by the interaction of two primary genes: the melanocortin-1 receptor $(M c 1 r)$, which encodes a seven-transmembrane receptor expressed in melanocytes, and its ligand, agouti, whose protein product is secreted from nearby dermal papilla cells and acts to inhibit Mc1r signaling (Figure 2a). In the absence of Agouti protein, basal levels of Mc1r activity keep levels of intracellular cyclic AMP (cAMP) sufficiently high to activate the eumelanin synthetic pathway. However, in the presence of Agouti protein, Mc1r activity is inhibited, cAMP levels are reduced, and melanocytes stop producing eumelanin and start producing pheomelanin. The interaction of these two proteins therefore plays a critical role in determining which pigment type is deposited along individual hairs.

Additional genes are known to alter the density and distribution of melanosomes (pigment granules) found in melanocytes. Tyrosinase, for example, is the ratelimiting enzyme in melanogenesis. There are over 100 alleles of tyrosinase that have been characterized, ranging a
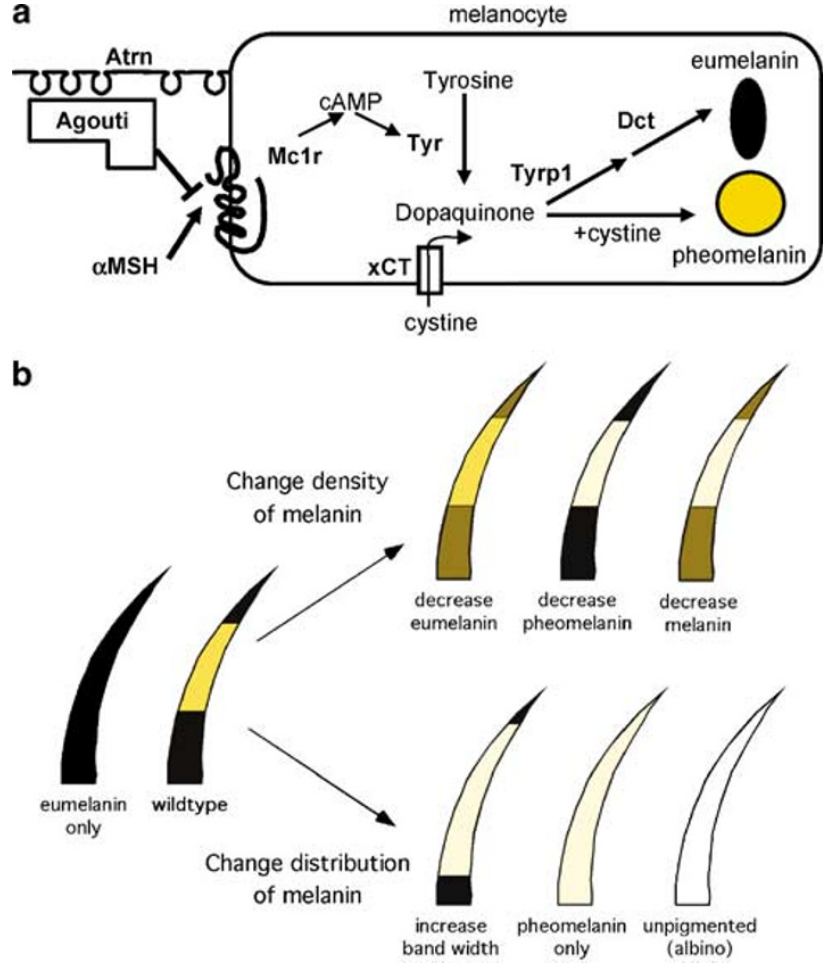

Figure 2 Genetic pathway regulating mammalian melanogenesis and phenotypic effects on individual hair pigment and pattern. (a) Circulating $\alpha$-MSH (a derivative of POMC) activates Mc1r, a G-protein-coupled transmembrane receptor, and signals via cAMP. Intracellularly, tyrosine is oxidized to dopaquinone, a reaction catalyzed by the enzyme tyrosinase (Tyr). Cyclic AMP is thought to affect the enzymatic activity of tyrosinase as well as eumelanicspecific enzymes, tyrosinase-related protein 1 (Tyrp1) and dopachrome tautomerase (Dct). When all three of these enzymes function properly, eumelanin (brown to black pigment) is deposited in melanosomes. Agouti, the inverse agonist of Mc1r, binds to Mc1r with the aid of the extracellular protein Atrn to repress intracellular cAMP levels, resulting in the 'switch' to the production of pheomelanin (yellow to red pigment). The production of pheomelanin is dependent on the incorporation of cystine, whose uptake is at least partially regulated by XCT (the Slc7a11 locus). (b) Overall coat color in mammals is determined by the density of melanin and the distribution of melanin (or melanin types) on individual hairs. Pigment on individual hairs ranges from fully pigmented with dark eumelanin to complete absence of pigment resulting in albino hairs. Typical wild-type hairs in mammals have a subterminal band of light-colored pheomelanin flanked by darker eumelanin, providing an overall brushed appearance.

from null alleles, resulting in the complete absence of pigmentation (albino), to alleles with reduced function that limit the production of melanin (Beermann et al, 2004). Other genes, such as tyrosinase-related protein-1 (Tyrp1) and dopachrome tautomerase (Dct or Tyrp2), primarily regulate the eumelanin pathway. Gammaglutamyl transpeptidase-encoding protein $(G g t)$ affects the production of pheomelanin, and more recently, a second gene specific to pheomelanogenesis was described, Slc7a11 (Chintala et al, 2005). In addition, several genes, Rab27a, Myo5a and Mlph, are well studied as models for organelle transport because they coordinate the transport and distribution of melanosomes, both eumelanosomes and pheomelanosomes, in melanocytes (Nascimento et al, 2003). Mutations in these genes disrupt melanosome organization and can dilute overall coloration. 
Clearly, many different molecular and developmental changes can affect the type, density and distribution of melanin on individual hairs and result in variation in overall pelage coloration (Figure $2 \mathrm{~b}$ ). Close examination of pigment and pattern on individual hairs can yield insight into the developmental changes and possible genes responsible for overall coloration. However, these candidates provide no guarantees - often changes in different genes can produce similar phenotypic effects.

\section{Comparative pigmentation}

Although the majority of our knowledge about the pigmentation pathway has been gathered in mammals in general, and laboratory mice in particular, the melanin pathway is highly conserved among vertebrates. However, modifications of this developmental pathway can generate dramatic variation in pigmenation among vertebrate taxa (Searle, 1968; Bagnara and Hadley, 1973). In mammals, melanocytes produce two types of pigment (eumelanin and pheomelanin), and the ratio of melanin types is largely responsible for variation in hair color. By comparison, variation in human skin color among ethnic groups has less to do with melanin ratio or even the number of melanocytes present, but instead is largely due to differences in melanosome size, number and density in the epidermis (Barsh, 2005). Birds, like mammals, produce both pigment types (for a review, see Mundy, 2005), but reptiles lack pheomelanin (Ito and Wakamatsu, 2003), suggesting that either reptiles have the lost the ability to produce pheomelanin or that mammals and birds independently have evolved the ability to produce pheomelanin. Given the similarities in the genetic and developmental mechanisms of pheomelanin production in birds and mammals (Boswell and Takeuchi, 2005), it seems unlikely that they have evolved independently, although this question warrants further investigation. Further, reptiles, amphibians and teleost fish can regulate body color by aggregation or concentration of melanin granules in melanocytes (also referred to as melanophores) via a mechanism controlled by the melaninconcentrating hormone (Kawauchi et al, 1983; Nery and Castrucci, 1997).

In addition to melanophores, amphibians, reptiles and teleosts have more diversity in chromatophores, including yellow/red carotenoid-containing xanthophores and reflective iridophores. Overall color and pattern result from the position and interaction among these differently colored chromatophores. Colors produced by xanthophore and iridiphore cells are particularly important for a number of classical traits involved in inter- and intra-specific communication, such as Anolis lizard dewlaps (Tokarz, 1995) and guppy spots (Endler, 1983). Studies in mice provide excellent candidate genes for melanin-based traits but provide little insight into the genetic mechanisms underlying non-melanin-based color traits. Recent work, primarily in zebrafish, has focused on understanding the genetic and developmental processes controlling these more colorful pigment cells (Kelsh, 2004) and will help identify the genetic basis of traits which rely on the interaction of multiple chromatophore cell types.

\section{Evolution: natural variation in pigmentation}

While pigmentation has served as a model for genetics and developmental biology, it has also played a prominent role in evolutionary biology. Naturally occurring color variation has served as a model for understanding local adaptation and ecologically mediated divergence and speciation. Such classic studies linking color variation to environmental heterogeneity span a broad taxonomic scale, from banding in Cepea snails (Sheppard, 1951) to melanism in peppered moths (Kettlewell, 1955) to patterning in water snakes (Camin and Ehrlich, 1958). Among the most comprehensive studies are those of cryptic coloration in rodents because early mammalogists documented variation in dorsal pigmentation, measured substrate color and later experimentally tested the adaptive significance of substrate-matching.

Starting in the early 1920s, classic work by museumbased natural historians linked dorsal coloration of diverse vertebrate species to environmental variation. In one seminal study, Dice and Blossom (1937) described the dramatic variation in coloration of vertebrates in the Tularosa Basin of New Mexico, where in less than $25 \mathrm{~km}$, the substrate color ranges from nearly black basaltic lava to brilliant white gypsum dunes. In particular, the dorsal pelage of pocket mice (genus Chaetodipus and Perognathus) ranges from nearly pure black to nearly pure white, closely matching the substrate on which the mice were caught (Figure 3). Around the same time, Sumner conducted a parallel study on the sandy dunes of Florida's Gulf and Atlantic coasts, documenting the extremely pale phenotypes of mice relative to their darker inland counterparts (Figure 1c and d, Sumner, $1929 a, b)$. However, unlike the pocket mice from New Mexico, most of the variation in these beach mice (genus Peromyscus) is reflected in patterning differences. Beach mice differ in a number of traits, such as the extent of tail striping and facial pigmentation, both between mainland and coastal populations and among coastal populations (Bowen, 1968). Genetic crossing experiments revealed that these patterning differences are heritable and likely controlled by just a few genes (Bowen and Dawson, 1977). Sumner's intensive sampling, documenting gradual change in pigmentation from coastal to mainland populations, later formed the basis for the first mathematical treatment of clinal variation and estimates of selection (Haldane, 1948). In addition, experimental studies of the adaptive significance of color variation show that substrate matching has a strong effect on predation rates by visual avian hunters (Dice, 1947; Kaufman, 1974). Adaptive substrate matching is not limited to mammals. Similar patterns of variation have been observed in many vertebrates, including lizards (Figure 3; Norris and Lowe, 1964), and corresponding selection experiments have been conducted (Luke, 1989). These early studies document ecologically relevant variation in pigmentation and elucidate the selective agents driving this variation.

These classic studies also provide striking examples of the independent evolution of similar phenotypes in similar habitats both within and among species. For example, rock pocket mice (Chaetodipus intermedius) have melanic morphs on geographically distant lava flows with little evidence of historical gene flow among them (Hoekstra et al, 2005). Similarly, beach mice (Peromyscus 

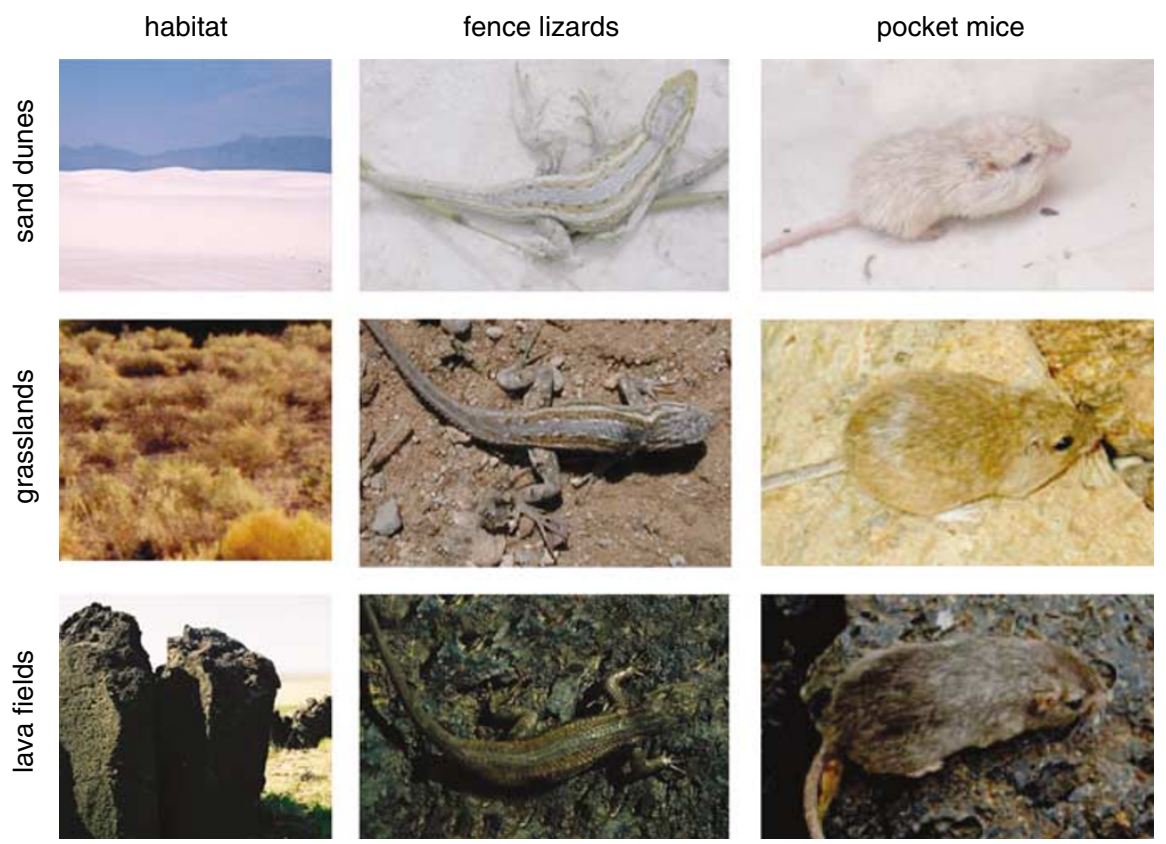

Figure 3 Convergent evolution of adaptive pigmentation in the Tularosa Basin of New Mexico. The Carrizozo lava field is separated from the gypsum sand dunes of White Sands by $25 \mathrm{~km}$ of desert grasslands. Western fence lizards, Sceloporus undulatus, rock pocket mice, Chaetodipus intermedius (melanic and wild-type morphs) and apache pocket mice, Perognathus flavescens (blanched morph) are pictured on the substrate where they were captured.

polionotus) have colonized both the Gulf and Atlantic coasts of Florida, and independently evolved similar light-colored dorsal coats (Bowen and Dawson, 1977; Hoekstra et al, in press). Independent convergence toward similar phenotypes is also observed among species. For example, three taxonomically diverse squamates have evolved blanched coloration in White Sands, New Mexico (Rosenblum, 2006). Observations of several different species of blanched and melanic animals ranging from lizards to pocket mice inhabiting the Tularosa Basin provide a dramatic example of convergent evolution over a broad taxonomic scale (Figure 3). Independent evolution of pigmentation and pattern has been observed in many vertebrate species, including poison frogs (Vences et al, 2003), orioles (Omland and Lanyon, 2000), cavefish (Strecker et al, 2003) and cichlid fish (Allender et al, 2003), and provides exciting opportunities to ask whether the same or different genes are responsible for convergent phenotypes.

\section{Linking genotype to phenotype}

The field of 'evo-devo' focuses on understanding the genetic and developmental mechanisms responsible for evolutionary changes in form among species. As a traditional model system, pigmentation provides (1) a plethora of candidate genes from studies in genetics, (2) an understanding of the role of these genes in pathways and networks from developmental biology and (3) ecologically relevant pigmentation phenotypes from studies in evolutionary biology. The integration of these resources makes pigmentation an ideal system in which to tackle several long-standing questions about the genetic and developmental basis of adaptive phenotypic variation.

One approach that has been successful in identifying the molecular basis underlying adaptive phenotypes is to focus on candidate genes. This approach is promising for studies of ecologically relevant color variation because of the wealth of knowledge of the genetic basis of color phenotype (eg, Table 2, Figure 2). Candidate gene approaches are necessarily limited in genomic scope, but can be especially useful in species that are not amenable to laboratory crosses or for which few genetic resources are available. For example, population-level association studies between nucleotide variation in candidate pigmentation genes and segregating color variation can provide statistical evidence that a particular gene is contributing to variation in color phenotype. However, such studies often are complicated by population structure, and require large sample sizes and functional assays to identify and verify the precise functionally relevant mutations. Despite these challenges, this approach has been especially successful for simple color polymorphisms segregating in natural populations of non-model organisms (eg, Ritland et al, 2001; Theron et al, 2001; Nachman et al, 2003; Mundy et al, 2004), although functional verification of the role of mutations in these genes is still needed. More recently, genetic and molecular tools have been developed for nontraditional species, which can be manipulated in the laboratory (eg oldfield mice (Peromyscus polionotus), threespine sticklebacks (Gasterosteus aculeatus), cavefish (Astyanax fasciatus)). In these systems, quantitative trait locus (QTL) mapping approaches provide a more comprehensive method for the identification of genetic regions underlying pigmentation variation and, when combined with candidate pigmentation genes, can provide an extremely powerful approach to make links between genes, phenotype and fitness.

Through both candidate gene and QTL approaches, a growing number of empirical studies have linked genetic variation to adaptive (nonpigmentation) traits (reviewed 
in Peichel, 2005). These studies have contributed to our understanding of several questions about the process of evolutionary change: (1) are changes in coding or regulatory regions differentially responsible for adaptive morphology? (2) are adaptive mutations generally dominant or recessive? and (3) are the same genes responsible for similar adaptive phenotypes? Recent success in identifying the genetic basis of pigmentation variation in natural populations of vertebrates provides additional, and sometimes surprising, insight into these questions. Together, these studies suggest that color adaptation does not follow a simple evolutionary route: mutations in both coding and regulatory regions, which are often dominant but other times recessive, contribute to pigmentation diversity in nature, and furthermore, sometimes the same but sometimes different, genetic mechanisms are involved in parallel and convergent color evolution in vertebrate populations.

\section{Insights into genetic mechanisms of adaptive evolution from pigmentation studies}

Mutations in both coding regions and regulatory regions have been identified and linked to adaptive variation for a variety of traits in a number of systems, but the relative prevalence of coding versus regulatory mutations in generating morphological diversity remains unknown (Coyne, 2005; Carroll, 2005a). King and Wilson (1975) originally argued that phenotypic change may largely be driven by changes in gene regulation, citing the extreme similarities in protein sequences between humans and chimpanzees despite their dramatic differences in morphology, physiology and behavior. More recently, mutations in regulatory regions have been proposed as a mechanism to fine-tune phenotypes because mutations in specific cis-regulatory elements may alter the expression of a protein in particular tissues, while preserving expression in others (Stern, 2000; Carroll et al, 2001; Carroll, 2005b). A handful of studies have already identified such mutations in cis-regulatory elements (eg Belting et al, 1998; Wang and Chamberlin, 2002; Gompel et al, 2005).

Functional changes in the coding region of $\mathrm{Mclr}$ represent some of the most striking exceptions to a growing consensus that most changes in morphology are governed by changes in gene regulatory regions. All known mutations in the Mc1r locus, many of which are adaptive, occur in the coding region, either as amino-acid changes or small deletions (Table 3, Majerus and Mundy, 2003). However, it is important to note that little is known about the regulatory mechanisms that govern the expression of Mc1r at the intracellular level (Rouzaud

Table 3 Pigmentation mutations segregating in natural populations of vertebrates

\begin{tabular}{|c|c|c|c|c|c|c|}
\hline Species $^{\mathrm{a}}$ & Gene & $\begin{array}{l}\text { Derived } \\
\text { phenotype }^{\mathrm{b}}\end{array}$ & Dominance & Mutation & $\begin{array}{l}\text { Adaptive } \\
\text { significance }\end{array}$ & Reference \\
\hline $\begin{array}{l}\text { Beach mice } \\
(P . \text { polionotus })\end{array}$ & $M c 1 r^{c}$ & $\begin{array}{l}\text { Pattern, } \\
\text { pheomelanic }\end{array}$ & Variable & Coding & Crypsis & Hoekstra et al (in press) \\
\hline $\begin{array}{l}\text { Pocket mice } \\
\text { (C. intermedius) }\end{array}$ & Mc1r & Eumelanic & Dominant & Coding & Crypsis & Nachman et al (2003) \\
\hline $\begin{array}{l}\text { Japanese wild mice } \\
\text { (Mus musculus molossinus) }\end{array}$ & Mc1r & Pheomelanic & Recessive & Coding & $?$ & Wada et al (1999) \\
\hline $\begin{array}{l}\text { Woolly mammoth } \\
\text { (Mammuthus primigenius) }\end{array}$ & $M c 1 r^{c}$ & $?$ & $?$ & Coding & $?$ & Rompler et al (in press) \\
\hline $\begin{array}{l}\text { Black bears } \\
\text { (Ursus americanus) }\end{array}$ & $M c 1 r$ & Pheomelanic & Recessive & Coding & $?$ & Ritland et al (2001) \\
\hline $\begin{array}{l}\text { Jaguar } \\
\text { (Panthera onca) }\end{array}$ & $M c 1 r$ & Eumelanic & Dominant & Coding & $?$ & Eizirik et al (2003) \\
\hline $\begin{array}{l}\text { Jaguarundi } \\
\text { (Herpailurus yaguarondi) }\end{array}$ & $M c 1 r$ & Eumelanic & Semi-dominant & Coding & $?$ & Eizirik et al (2003) \\
\hline $\begin{array}{l}\text { Bananaquit } \\
\text { (Coereba flaveola) }\end{array}$ & $M c 1 r$ & Eumelanic & Dominant & Coding & $?$ & Theron et al (2001) \\
\hline $\begin{array}{l}\text { Arctic skua } \\
\text { (Stercorarius parasiticus) }\end{array}$ & $M c 1 r$ & Eumelanic & Semidominant & Coding & Mate choice & Mundy et al (2004) \\
\hline $\begin{array}{l}\text { Lesser snow geese } \\
\text { (Anser c. caerulescens) }\end{array}$ & $M c 1 r$ & $\begin{array}{l}\text { Pattern; } \\
\text { eumelanic }\end{array}$ & Semidominant & Coding & Mate choice & Mundy et al (2004) \\
\hline $\begin{array}{l}\text { Little striped whiptail } \\
\text { (Aspidoscelis inornata) }\end{array}$ & $M c 1 r$ & Blanched & $?$ & Coding & Crypsis & Rosenblum et al (2004) \\
\hline $\begin{array}{l}\text { Lesser earless lizard } \\
\text { (Holbrookia maculata) }\end{array}$ & $M c 1 r$ & Blanched & $?$ & Coding & Crypsis & Rosenblum et al (2004) \\
\hline $\begin{array}{l}\text { Deer mice } \\
\text { (P. maniculatus) }\end{array}$ & Agouti & Pheomelanic & Dominant & $?$ & Crypsis & $\begin{array}{l}\text { Dodson (1982) and } \\
\text { Hoekstra et al in } \\
\text { preparation }\end{array}$ \\
\hline $\begin{array}{l}\text { Mexican tetra (cave fish; } \\
\text { A. fasciatus) }\end{array}$ & $\mathrm{Oca} 2^{c}$ & Albino & Recessive & Coding & $?$ & Protas et al (2006) \\
\hline Pachón population & & & & \multirow{3}{*}{\multicolumn{3}{|c|}{$\begin{array}{l}\text { (deletion of exon 21) } \\
\text { (deletion of exon 24) } \\
\text { (unidentified) }\end{array}$}} \\
\hline Molino population & & & & & & \\
\hline Japonés population & & & & & & \\
\hline
\end{tabular}

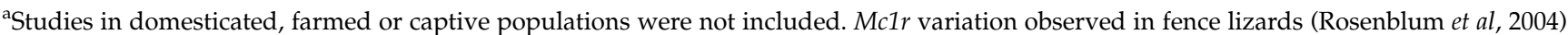
and fairy-wrens (Doucet et al, 2004) was not included because of the confounding effects of population structure in these association studies. ${ }^{b}$ Derived phenotypes (as reported in each study) are categorized as follows: pattern, change in distribution of pheomelanin and eumelanin across the body; pheomelanic, predominately or exclusively pheomelanin; eumelanic, exclusively or predominantly eumelanin; blanched, reduction in the amount of eumelanin (pheomelanin is not present in reptiles); albino, complete loss of melanin.

'Studies in which mutation(s) in pigmentation gene were functionally characterized and verified. 
and Hearing, 2005), and that bias toward discovering these coding sequence changes may be due to the ease of assaying $M c 1 r$ across vertebrates (based on its conserved structure and single $1 \mathrm{~kb}$ exon). Nonetheless, it is certainly possible to change protein structure without measurable antagonistic effects on other traits as demonstrated by amino-acid change in Mc1r and deletions in Oca2 in albino cavefish (Protas et al, 2006). Like Mc1r, proteins that are specific to given cell or tissue type or occur late in developmental pathways may be particularly good candidates for adaptive coding region change.

However, variation in pigmentation certainly will not be caused only by changes in protein structure. For example, variation in pigmentation pattern is likely driven by changes in the spatial regulation of pigment rather than changes in the pigments themselves; however, this process may involve mutations in cis-regulatory regions of pigment genes or changes (either coding or regulatory) in upstream transcription factors. One promising area for future research focuses on Mclr's agonist, Agouti, which is known to produce similar whole-body changes in coloration, but can also have more subtle effects on color as well as alter the spatial distribution of pigmentation. And by contrast, mutations in Agouti, unlike $M c 1 r$, are likely to be regulatory. The vast majority of known mutations in the Agouti gene that cause subtle changes in pigmentation phenotypes in laboratory mice occur at the level of Agouti expression, whereas the complete abrogation of Agouti occurs through lesions in the Agouti coding region (Miltenberger et al, 2002). Because the upstream cis-regulatory region of Agouti is modular, that is, several wellcharacterized regulatory elements can independently affect Agouti's spatial expression, Agouti is relatively free of pleiotropic consequences (Figure 4). Association studies with Agouti will likely be more difficult than those with Mc1r given that the majority of alleles described in laboratory mice are caused by mutations embedded in the large, albeit well-characterized, regulatory region, which spans over $100 \mathrm{~kb}$ in mice. Thus, association studies in Agouti may only be feasible in cases of strong and recent selection and/or in low recombination rate regions, where one would expect the extent of linkage disequilibrium to be large. However, genetic crosses in deer mice, Peromyscus maniculatus,
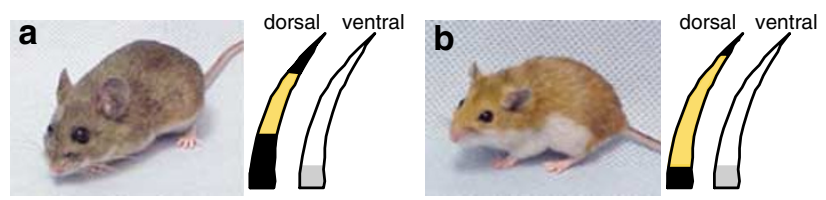

C

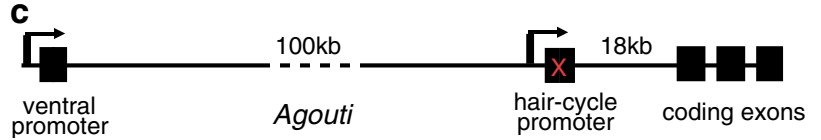

Figure 4 Agouti is a strong candidate gene for variation in vertebrate pigmentation and patterning in natural populations. (a) Deer mice (P. maniculatus) have banded dorsal hairs and lightcolored ventral hairs. (b) Deer mice, which inhabit the light-colored Sand Hills in Nebraska, have dorsal hairs with a wider subterminal band, generating an overall golden color, better matched to the lighter sandy substrate they inhabit. (c) Mutations in Agouti's dorsal promoter region provide a plausible mechanism for the observed phenotypic change in dorsal but not ventral pigmentation. have already pointed to regulatory changes in Agouti as being responsible for adaptive coloration (Figure 4, Hoekstra et al, in preparation; Dice, 1941; McIntosh, 1956; Dodson, 1982). Therefore, as is the case for most adaptive traits, variation in adaptive pigmentation is likely caused by a combination of changes in both coding (eg, Mc1r) and noncoding DNA (eg, Agouti).

A second major question about the process of adaptation is the relative contribution of dominant versus recessive mutations to adaptive change. JBS Haldane (1924) suggested that adaptation is driven by the fixation of dominant mutations because of the bias against the establishment of recessives, termed 'Haldane's sieve' (although this prediction may not hold for deleterious mutations previously maintained at mutation-selection balance (Orr and Betancourt 2001)). Empirical data from pigmentation genes in natural populations can be used to address Haldane's prediction (Table 3). Melanism has evolved repeatedly in vertebrates, likely driven by both natural and sexual selection. In several cases, melanism has been linked to dominant or semidominant mutations in the Mc1r locus (Majerus and Mundy, 2003; Mundy, 2005), likely causing hyper or constitutive activation of Mc1r. Because of the nature of pigmentation-type switching, recessive null mutations in several other genes, such as agouti, attractin or mahogunin, can also result in similar melanic phenotypes in laboratory mice (Figure 2). Although additional genes which can cause melanism have not been surveyed to the extent of $M c 1 r$, in part because of their complex genomic structure, mutations in these loci have yet to be linked to melanic forms in nature.

These few observations support the notion that dominant mutations often contribute to adaptive phenotypes. However, there are three notable exceptions (Table 3). First, in cavefish, multiple populations have lost pigmentation through recessive null alleles at the Oca2 locus (Protas et al, 2006). Second, recessive alleles of $\mathrm{Mc1r}$ are likely responsible for pale coloration in black bears (Ritland et al, 2001) and Japanese wild mice (Wada et al, 1999). However, in all three of these cases, the adaptive significance of the color variation remains unclear. Third, blanched forms of two lizard species are associated with mutations in $M c 1 r$ (although breeding studies have not been conducted, based on Mc1r's function, we predict that these are null or reduced function alleles) (Rosenblum et al, 2004). In pigmentation studies, recessive null alleles often (although not always) result in lighter coloration (loss or reduction of pigmentation), whereas dominant mutations are often associated with darker color (gain of pigmentation). Thus, like for pigmentation traits, the contribution of dominant versus recessive alleles to evolutionary change may be confounded by whether the traits of interest represent loss of structures, where loss-of-function, recessive null alleles may prevail, or the gain of novel structures.

A third fundamental question about the adaptive process focuses on the role of developmental constraint in directing evolutionary change. It has been predicted that the same genes will often underlie parallel changes in closely related organisms because there are only a limited number of genetic changes free of antagonistic pleiotropic effects (Haldane, 1932; Gould and Lewontin, 1979; Maynard Smith et al, 1985). Studies of pigmentation variation are particularly appropriate for addressing this 
question because of the many examples of convergent and parallel evolution in color (eg, Figure 3). While similar pigmentation phenotypes have evolved repeatedly among divergent taxa as well as within species, there are also hundreds of genes that encode different developmental mechanisms and are known to affect pigmentation (Table 2). Despite the wealth of genes involved in the vertebrate pigmentation pathway, one of the most striking examples of molecular convergence stems from studies of $M c 1 r$ in a wide variety of vertebrate taxa. Perhaps the most intriguing example involves mice and mammoths: a single amino-acid change (Arg ${ }^{65} \mathrm{Cys}$ ) contributes to adaptive light coloration in beach mice (Hoekstra et al, in press) and the identical amino-acid change at the homologous position is segregating in woolly mammoths (identified through ancient DNA studies), suggesting that mammoths may also have been polymorphic in color (Rompler et al, in press). In addition, $M c 1 r$ has been repeatedly co-opted in the evolution of melanic forms (Table 3). However, while $M c 1 r$ is thus far the only gene linked to melanism in natural populations of vertebrates, already several genes (including $\mathrm{Mc1}$, agouti and Oca2) have been linked to light-color or albino phenotypes, suggesting that there may be few ways to 'gain' pigmentation but many ways to 'lose' pigmentation.

So the question remains: why is $M c 1 r$ repeatedly coopted for adaptation? Perhaps the most compelling argument is that $M c 1 r$ appears to be largely free from pleiotropic effects (Mundy, 2005); in other words, changes in $M c 1 r$ appear to be specific to pigmentation and, thus, free from developmental constraints. Mc1r is also part of a larger melanocortin gene family (Mc1rMc5r), whose members are specialized in their tissue expression and are involved in diverse pathways from pigmentation to energy homeostasis (Schioth, 2001). Such duplication events allow for fine-tuning of mutational effects analogous to modularity in cis-regulatory regions. In other words, specific amino-acid mutations in specific melanocortin receptors can alter protein function in some tissues while preserving function in other tissues or pathways. Additionally, there are many changes in Mc1r that produce large (beneficial) phenotypic effects. Therefore, despite its small target size (less than $1 \mathrm{~kb}$ ), there are several possible mutations, even single aminoacid changes, that can produce a wide range of phenotypes from complete eumelanism (eg, pocket mice, bananaquits, jaguars) to complete pheomelanism (eg, black bears, Japanese wild mice) as well as intermediate patterning phenotypes (eg, beach mice, snow geese).

While mutations in Mclr are associated with color variation in a wide variety of taxa, there are also several examples within species where some populations utilize $M c 1 r$ for color adaptation and other populations in similar selective environments use other genes. For example, while beach mice inhabiting the sandy dunes of the Gulf Coast of Florida have a single amino-acid change in $M c 1 r$, which contributes to their light coloration relative to their mainland counterparts, beach mice on the Atlantic coast of Florida do not share this mutation in $M c 1 r$, despite the similarity in adaptive color phenotype and selective environment (Hoekstra et al, in press). Similarly, lava-dwelling pocket mice in Arizona have a melanic phenotype caused by amino-acid mutations in Mc1r; however, geographically distant lava populations in New Mexico, which also harbor melanic mice, do not share these mutations or have any new mutations in $\mathrm{Mclr}$ associated with melanism (Hoekstra and Nachman, 2003). It is also important to note that many melanic organisms are not associated with mutations in $M c 1 r$, suggesting that other genes are responsible for their melanic coloration (MacDougall-Shackleton et al, 2003; Mundy and Kelly, 2003; Rosenblum et al, 2004). Understanding why sometimes the same gene is responsible for convergent evolution between divergent taxa and other times different genes are involved remains an interesting but largely unanswered question.

Understanding the nature of adaptive change in wild populations requires knowledge of multiple adaptive traits in taxonomically diverse systems. While pigmentation represents a particularly amenable phenotype in which to link phenotypic variation to genes in vertebrates (as is true for the invertebrate pigmentation system (True, 2003) and the anthocyanin pathway in plants (Holton and Cornish, 1995)), analysis of additional traits, including morphological, physiological and behavioral characters, is essential. The growing number of molecular markers and complete genome sequences from diverse organisms represents a major step toward developing additional non-model systems in which to identify the genetic basis of adaptation.

\section{Conclusions}

The prominent role of pigmentation biology in laying the conceptual foundations of genetics, development and evolutionary biology have since resulted in a wealth of knowledge about the genes, pathways and adaptive significance of pigmentation in vertebrates. This background has made it increasingly possible to identify the genetic basis of pigmentation variation in natural populations, identifying the genes, and in some cases the mutations, underlying adaptive traits. These recent advances have begun to shed additional light onto fundamental questions about the process of adaptation. However, future work that (1) continues to identify genes involved in pigmentation in laboratory mice and other organisms, (2) dissects the developmental mechanisms responsible for color patterning and (3) identifies the genes underlying ecologically relevant traits (including color and color pattern) in taxonomically diverse systems will contribute to a more comprehensive glimpse into the genetic and developmental mechanisms underlying organismal diversity.

\section{Acknowledgements}

Discussions and comments from G Barsh, P Brakefield, J Endler, V French, B Payseur, T Price, E Rosenblum, C Steiner, J Weber and members of my laboratory greatly improved this manuscript. G Barsh and S Candille kindly provided photographs of droopy ear mutant mice, and E Rosenblum provided photographs of lizards. Work in my laboratory is funded by the National Science Foundation.

\section{References}

Allender CJ, Seehausen O, Knight ME, Turner GF, Maclean N (2003). Divergent selection during speciation of Lake Malawi 
cichlid fishes inferred from parallel radiations in nuptial coloration. Proc Natl Acad Sci USA 100: 14074-14079.

Bagnara JT, Hadley ME (1973). Chromatophores and Color Change: The Comparative Physiology of Animal Pigmentation. PrenticeHall, Inc.: Englewood Cliffs, NJ.

Bard JBL (1977). A unity underlying the different zebra striping patterns. J Zool 183: 527-539.

Barsh GS (1996). The genetics of pigmentation: from fancy genes to complex traits. Trends Genet 12: 299-305.

Barsh GS (2005). What controls variation in human skin color? Plos Biol 1: 19-22.

Baxter LL, Hou L, Loftus SK, Pavan WJ (2004). Spotlight on spotted mice: a review of white spotting mouse mutants and associated human pigmentation disorders. Pigment Cell Res 17: 215-224.

Beermann F, Orlow SJ, Lamoreux ML (2004). The Tyr (albino) locus of the laboratory mouse. Mamm Genome 15: 749-758.

Belting HG, Shashikant CS, Ruddle FH (1998). Modification of expression and cis-regulation of Hoxc8 in the evolution of diverged axial morphology. Proc Natl Acad Sci 95: 2355-2360.

Bennett DC, Lamoreux ML (2003). The color loci of mice - a genetic century. Pigment Cell Res 16: 333-334.

Benson SB (1933). Concealing coloration among some desert rodents of the Southwestern United States. Univ Calif Publicat Zool 40: 1-69.

Boswell T, Takeuchi S (2005). Recent developments in our understanding of the avian melanocortin system: its involvement in the regulation of pigmentation and energy homeostasis. Peptides 26: 1733-1743.

Bowen WW (1968). Variation and evolution of Gulf Coast populations of beach mice, Peromyscus polionotus. Bull Florida State Museum 12: 1-91.

Bowen WW, Dawson WD (1977). Genetic analysis of coat color pattern variation in oldfield mice (Peromyscus polionotus) of Western Florida. J Mammal 58: 521-530.

Brakefield PM, French V, Zwaan BJ (2003). Development and the genetics of evolutionary change within insect species. Annu Rev Ecol Syst 34: 633-660.

Bultman SJ, Klebig ML, Michaud EJ, Sweet HO, Davisson MT, Woychik RP (1994). Molecular analysis of reverse mutations from nonagouti $(a)$ to black-and-tan $\left(a^{t}\right)$ and white-bellied agouti $\left(A^{w}\right)$ reveals alternative forms of agouti transcripts. Genes Dev 8: $481-490$.

Bultman SJ, Michaud EJ, Woychik RP (1992). Molecular characterization of the mouse agouti locus. Cell 71: 1195-1204.

Camin JH, Ehrlich PR (1958). Natural selection in water snakes (Natrix sipedon L.) on islands in Lake Erie. Evolution 12: 504-511.

Candille SI, Van Raamsdonk CD, Chen CY, Chen S, Kuijper Y, Chen-Tsai A et al (2004). Dorsoventral patterning of the mouse coat by Tbx15. Plos Biol 2: 30-42.

Caro $\mathrm{T}$ (2005). The adaptive significance of coloration in mammals. Bioscience 55: 125-136.

Carroll SB (2005a). Endless Forms Most Beautiful: the New Science of Evo-Devo. W.W. Norton \& Co., Inc.: New York.

Carroll SB (2005b). Evolution at two levels: on genes and form. Plos Biol 3: 1159-1166.

Carroll SB, Grenier JK, Weatherbee SD (2001). From DNA to Diversity: Molecular Genetics and the Evolution of Animal Design. Blackwell: Oxford.

Castle WE, Allen G (1903). The heredity of albinism. Proc Am Acad Arts Sci 38: 603-621.

Chintala S, Li W, Lamoreux M, Ito S, Wakamatsu K, Sviderskaya E et al (2005). Slc7a11 gene controls production of pheomelanin pigment and proliferation of cultured cells. Proc Natl Acad Sci 102: 10964-10969.

Cott H (1940). Adaptive Colouration in Animals. Methuen and Co.: London, UK.

Coyne JA (2005). Switching on evolution. Nature 435: 1029-1030.

Cuénot L (1904). L'heredite de la pigmentation chez les souris. Arch Zoo Exp Get 2: 45-56.
Davis PA, Justice MJ (1998). An Oak Ridge legacy: the specific locus test and its role in mouse mutagenesis. Genetics 148: 7-12.

Dice LR (1941). Variation of the deer-mouse (Peromyscus maniculatus) on the Sand Hills of Nebraska and adjacent areas. Contribut Lab Vertebrate Biol, Univ Michigan 15: 1-19.

Dice LR (1947). Effectiveness of selection by owls of deer mice (Peromyscus maniculatus) which contrast with their background. Contrib Vertebrate Biol Lab Univ Michigan 34: 1-20.

Dice LR, Blossom PM (1937). Studies of mammalian ecology in Southwestern North America, with special attention to the colors of desert mammals. Publ Carnegie Inst Washington 485: $1-25$.

Dodson KM (1982). Genetic Linkage Relationships Among Several Coat Color Mutations in the Deer Mouse (Peromyscus maniculatus). Masters, University of South Carolina.

Doucet SM, Shawkey MD, Rathburn MK, Mays HL, Montgomerie R (2004). Concordant evolution of plumage colour, feather microstructure and a melanocortin receptor gene between mainland and island populations of a fairywren. Proc Roy Soc B-Biol Sci 271: 1663-1670.

Eizirik E, Yuhki N, Johnson WE, Menotti-Raymond M, Hannah SS, O'Brien SJ et al (2003). Molecular genetics and evolution of melanism in the cat family. Curr Biol 13: 448-453.

Endler JA (1983). Natural and sexual selection on color patterns in poeciliid fishes. Environ Biol Fishes 9: 173-190.

Endler JA (1990). On the measurement and classification of color in studies of animal coloration. Biol J Linnean Soc 41: 315-352.

Gompel N, Prud'homme B, Wittkopp PJ, Kassner VA, Carroll SB (2005). Chance caught on the wing: cis-regulatory evolution and the origin of pigment patterns in Drosophila. Nature 433: 481-487.

Gould SJ, Lewontin RC (1979). The spandrels of San Marco and the Panglossian paradigm: a critque of the adaptionist programme. Proc R Soc B-Biol Sci 205: 581-598.

Haffter P, Odenthal J, Mullins MC, Lin S, Farrell MJ, Vogelsang $E$ et al (1996). Mutations affecting pigmentation and shape of the adult zebrafish. Dev Genes Evol 206: 260-276.

Haldane JBS (1924). A mathematical theory of natural and artificial selection, Part 1. Trans Camb Philos Soc 23: 19-41.

Haldane JBS (1932). The Causes of Evolution. Harper and Brothers: London.

Haldane JBS (1948). The theory of a cline. J Genet 48: 277-284.

Haldane JBS, Sprunt AD, Haldane NM (1915). Reduplication in mice. J Genet 5: 133-135.

Hoekstra HE, Hirschmann RJ, Bundey RA, Insel PA, Crossland JP (2006). A single amino acid contributes to adaptive beach mouse color pattern. Science 313: 101-104.

Hoekstra HE, Krenz JG, Nachman MW (2005). Local adaptation in the rock pocket mouse (Chaeotdipus intermedius): natural selection and phylogenetic history of populations. Heredity 94: 217-228.

Hoekstra HE, Nachman MW (2003). Different genes underlie adaptive melanism in different populations of rock pocket mice. Mol Ecol 12: 1185-1194.

Holton TA, Cornish EC (1995). Genetics and biochemistry of anthocyanin biosynthesis. Plant Cell 7: 1071-1083.

Houzelstein D, Cheraud Y, Auda-Boucher G, Fontaine-Perus J, Robert B (2000). The expression of the homeobox gene Msx1 reveals two populations of dermal progenitor cells originating from the somites. Development 127: 2155-2164.

Ito S, Wakamatsu K (2003). Quantitative analysis of eumelanin and pheomelanin in humans, mice and other animals: a comparative review. Pigment Cell Res 16: 523-531.

Jackson IJ (1988). A cDNA encoding tyrosinase-related protein maps to the brown locus in mouse. Proc Natl Acad Sci 85: 4392-4396.

Jackson IJ (1994). Molecular and developmental genetics of mouse coat color. Annu Rev Genet 28: 189-217. 
Kaufman DW (1974). Adaptive coloration in Peromyscus polionotus: experimental selection by owls. J Mammal 55: 271-283.

Kawauchi H, Kawazoe I, Tsubokawa M, Kishida M, Baker BI (1983). Characterization of melanin-concentrating hormone in chum salmon pituitaries. Nature 305: 321-323.

Kelsh RN (2004). Genetics and evolution of pigment patterns in fish. Pigment Cell Res 17: 326-336.

Kelsh RN, Inoue C, Momoi A, Kondoh H, Furutani-Seiki M, Ozato $\mathrm{K}$ et al (2004). The Tomita collection of medaka pigmentation mutants as a resource for understanding neural crest cell development. Mech Dev 121: 841-859.

Kettlewell HBD (1955). Selection experiments on industrial melanism in the Lepidoptera. Heredity 9: 323-342.

King MC, Wilson AC (1975). Evolution at two levels in humans and chimpanzees. Science 188: 107-116.

Kwon BS, Haq AK, Wakulchik M, Kestler D, Barton DE, Francke $U$ et al (1989). Isolation, chromosomal mapping, and expression of the mouse tyrosinase gene. J Invest Dermatol 93: 589-594.

Lamason RL, Mohideen MA, Mest JR, Wong AC, Norton HL, Aros MC et al (2006). SLC24A5, a putative cation exchanger, affects pigmentation in zebrafish and humans. Science 310: 1782-1786.

Lewontin R (1974). The Genetic Basis of Evolutionary Change. Columbia University Press: New York, NY.

Little C (1917). Evidence of multiple factors in mice and rats. Am Natur 51: 457-480.

Luke CA (1989). Color as a Phenotypically Plastic Character in the Side-Blotched Lizard, Uta Stansburiana, PhD, University of California.

MacDougall-Shackleton EA, Blanchard L, Gibbs HL (2003). Unmelanized plumage patterns in old world leaf warblers do not correspond to sequence variation at the Melanocortin-1 receptor locus. Mol Biol Evol 20: 1675-1681.

Majerus MEN, Mundy NI (2003). Mammalian melanism: natural selection in black and white. Trends Genet 19: 585-588.

Maynard Smith J, Burian R, Kauffman S, Alberch P, Campbell J, Goodwin B et al (1985). Developmental constraints and evolution. Q Rev Biol 60: 265-287.

McIntosh WB (1956). Linkage in Peromyscus and sequential tests for independent assortment. Contrib Lab Vertebr Biol, Univ Michigan 73: 1-27.

Miller MW, Duhl DMJ, Vrieling H, Vrieling H, Cordes SP, Ollmann MM et al (1993). Cloning of the mouse agouti gene predicts a secreted protein ubiquitously expressed in mice carrying the lethal yellow mutation. Genes Dev 7: 454-467.

Millar SE, Stevens M, Barsh GS (1995). Expression and transgenic studies of the mouse agouti gene provide insight into the mechanisms by which mammalian coat color patterns are generated. Development 10: 3223-3232.

Miltenberger RJ, Wakamatsu K, Ito S, Woychik RP, Russell LB, Michaud EJ (2002). Molecular and phenotypic analysis of 25 recessive, homozygous-viable alleles at the mouse agouti locus. Genetics 160: 659-674.

Morse H (1978). Introduction. In: Morse H (ed) Origins of Inbred Mice. Academic: New York. pp 1-31.

Mouse Genome Database (2006). Mouse Genome Informatics. The Jackson Laboratory: Harbor, Maine.

Mundy NI (2005). A window on the genetics of evolution: MC1R and plumage colouration in birds. Proc Roy Soc B-Biol Sci 272: 1633-1640.

Mundy NI, Badcock NS, Hart T, Scribner K, Janssen K, Nadeau NJ (2004). Conserved genetic basis of a quantitative plumage trait involved in mate choice. Science 303: 1870-1873.

Mundy NI, Kelly J (2003). Evolution of a pigmentation gene, the melanocortin-1 receptor, in primates. Am J Phys Anthropol 121: $67-80$

Nachman MW, Hoekstra HE, D’Agostino SL (2003). The genetic basis of adaptive melanism in pocket mice. Proc Natl Acad Sci 100: $5268-5273$.
Nascimento AA, Roland JT, Gelfand VI (2003). Pigment cells: a model for the study of organelle transport. Annu Rev Cell Dev Biol 19: 469-491.

Nery LM, Castrucci AMD (1997). Pigment cell signaling for physiological color change. Comp Biochem Physiol 118: 11351144.

Norris KS, Lowe CH (1964). An analysis of background colormatching in amphibians and reptiles. Ecology 45: 565-580.

Odenthal J, Rossnagel K, Haffter P, Kelsh RN, Vogelsang E, Brand $\mathrm{M}$ et al (1996). Mutations affecting xanthophore pigmentation in the zebrafish, Danio rerio. Development $\mathbf{1 2 3}$ 391-398.

Omland KE, Lanyon SM (2000). Reconstructing plumage evolution in orioles (Icterus): repeated convergence and reversal in patterns. Evolution 54: 2119-2133.

Orr HA, Betancourt AJ (2001). Haldane's sieve and adaptation from standing genetic variation. Genetics 157: 875-884.

Parichy DM (2003). Pigment patterns: fish in stripes and spots. Curr Biol 13: R947-R950.

Peichel CL (2005). Fishing for the secrets of vertebrate evolution in threespine sticklebacks. Dev Dynam 234: 815-823.

Protas ME, Hersey C, Kochanek D, Zhou Y, Wilkens H, Jeffery WR et al (2006). Genetic analysis of cavefish reveals molecular convergence in the evolution of albinism. Nat Genet 38: 107-111.

Ritland K, Newton C, Marshall HD (2001). Inheritance and population structure of the white-phased 'Kermode' black bear. Curr Biol 11: 1468-1472.

Rompler H, Rohland N, Lalueza-Fox C, Willerslev E, Kuznetsova T, Rabeder G et al (2006). Nuclear gene indicates coatcolor polymorphism in mammoths. Science 313: 62 .

Rosenblum EB (2006). Convergent evolution and divergent selection: lizards at the White Sands ecotone. Am Natur 167: 1-15.

Rosenblum EB, Hoekstra HE, Nachman MW (2004). Adaptive reptile color variation and the evolution of the MC1R gene. Evolution 58: 1794-1808.

Rouzaud F, Hearing VJ (2005). Regulatory elements of the melanocortin 1 receptor. Peptides 26: 1858-1870.

Russell LB, Major MH (1957). Radiation-induced presumed somatic mutations in the house mouse. Genetics 42: 161-175.

Russell WL (1951). X-ray induced mutations in mice. Cold Spring Harbor Symp Quant Biol 16: 327-335.

Schioth HB (2001). The physiological role of melanocortin receptors. Vitam Horm 63: 195-232.

Schlager G, Dickie MM (1966). Spontaneous mutation rates at five coat-color loci in mice. Science 151: 205-206.

Schlager G, Dickie MM (1967). Spontaneous mutations and mutation rates in the house mouse. Genetics 57: 319-330.

Searle A (1968). Comparative Genetics of Coat Colour in Mammals. Logos Press: London.

Sheppard PM (1951). Fluctuations in the selective values of certain phenotypes in the polymorphic land snails Cepea nemoralis. Heredity 5: 125-134.

Shibahara S, Tomita V, Sakakura T, Nager C, Chaudhuri B, Muller R (1986). Cloning and expression of cDNA-encoding mouse tyrosinase. Nucleic Acids Res 14: 2413-2427.

Silvers WK (1979). The Coat Colors of Mice: a Model for Mammalian Gene Action and Interaction. Springer-Verlag: New York.

Stern DL (2000). Evolutionary developmental biology and the problem of variation. Evolution 54: 1079-1091.

Strecker U, Bernatchez L, Wilkens H (2003). Genetic divergence between cave and surface populations of Astyanax in Mexico (Characidae, Teleostei). Mol Ecol 12: 699-710.

Sumner FB (1921). Desert and lava-dwelling mice and the problem of protective coloration in mammals. J Mammal 2: 75-86.

Sumner FB (1929a). The analysis of a concrete case of intergradation between two subspecies. Proc Natl Acad Sci USA 15: 110-120. 
Sumner FB (1929b). The analysis of a concrete case of intergradation between two subspecies. II. Additional data and interpretations. Proc Natl Acad Sci USA 15: 481-493.

Thayer A (1909). Concealing Coloration in the Animal Kingdom. Macmillan: New York.

Theron E, Hawkins K, Bermingham E, Ricklefs RE, Mundy NI (2001). The molecular basis of an avian plumage polymorphism in the wild: a melanocortin-1-receptor point mutation is perfectly associated with the melanic plumage morph of the bananaquit, Coereba flaveola. Curr Biol 11: 550-557.

Tokarz RR (1995). Mate choice in lizards: a review. Herptol Monogr 9: 17-40.

True JR (2003). Insect melanism: the molecules matter. Trends Ecol Evol 18: 640-647.

Vences M, Kosuch J, Boistel R, Haddad CFB, La Marca E, Lotters S et al (2003). Convergent evolution of aposematic coloration in Neotropical poison frogs: a molecular phylogenetic perspective. Organisms Diversity Evol 3: 215-226.
Vrieling H, Duhl DMJ, Millar SE, Miller KA, Barsh GS (1994). Differences in dorsal and ventral pigmentation result from regional expression of the mouse agouti gene. Proc Natl Acad Sci USA 91: 5667-5671.

Wada A, Okumoto M, Tsudzuki M (1999). Tawny: a novel light coat color mutation found in a wild population of Mus musculus molossinus, a new allele at the melanocortin 1 receptor (Mc1r) locus. Exp Animals 48: 73-78.

Wang X, Chamberlin HM (2002). Multiple regulatory changes contribute to the evolution of the Caenorhabditis lin-48 ovo gene. Genes Dev 16: 2345-2349.

Winge $\varnothing$ (1927). The location of 18 genes in Lebistes reticulatus. J Genet 18: 1-43.

Wright S (1917a). Color inheritance in mammals - I. J Hered 8: 224-235.

Wright S (1917b). Color inheritance in mammals - II. The mouse. J Hered 8: 373-378.

Wright S (1917c). Color inheritance in mammals -III. The rat. J Hered 8: 426-430.

Wright S (1917d). Color inheritance in mammals - V. The guinea pig. J Hered 8: 476-480. 